\section{Depicting A POLITICAL Rival: EVOLUTION OF RICHARD STEELE'S ESSAY PERIODICAL WRITING}

Brno Studies in English

Volume 46, No. 2, 2020

ISSN 0524-6881 | e-ISSN 1805-0867 https://doi.org/10.5817/BSE2020-2-11

\title{
KATARZYNA KOZAK
}

\begin{abstract}
The period between the Glorious Revolution and the end of Queen Anne's reign was a time when political parties struggled with one another in order to create their own distinctive identity. The rivalry between Whigs and Tories defined the political situation in early eighteenthcentury Britain and laid the foundation for the development of the ministerial machine of propaganda aimed at discrediting opponents and justifying the policies of the government. The rhetoric adopted by the contemporary political writers included the reason-passion bias so inextricably associated with the philosophical background of the 'Age of Reason'. From this perspective, this article sets out to trace the evolution in Steele's journalistic productions (The Spectator, The Englishman, The Reader) and to delineate key changes in his strategies for achieving political goals and, at the same time, discredit his rival paper - The Examiner.
\end{abstract}

Key words

Joseph Addison; Whig; Tory; essay periodical; propaganda; eighteenth century

\section{Introduction}

The period between the Glorious Revolution and the end of Queen Anne's reign was a time when political parties struggled with one another in order to create their own distinctive identity. The complexity of the contemporary scene, with its rich variety of political and religious groupings (Tories, Whigs, Jacobites, High Churchmen, Dissenters, Latitudinarians), was visible in the multi-layered differences embracing the principal attitude towards the Glorious Revolution. At the beginning of the eighteenth century a two-party system emerged, though it was not yet fully visible on an ideological level which either absorbed other politicalreligious groups or made them seem radical. However, for the purposes of clarity, a more simplified binary opposition of Whig and Tory will be presented in this present study.

There were two key factors that significantly helped these two emerging parties become the most politically influential factions. Firstly, under the Triennial Act (passed at the end of 1694), elections had to be held every three years; and, secondly, the expiration of the licensing act in 1695 removed the pre-publication censorship for English newspapers. As a result, the decades between the Glorious Revolution and the Hannoverian Succession in 1715 are often referred to as 'The Rage of the Party' expressed through political literature. The first years of this massive increase in political propaganda left the administrations reduced to 
helpless and passive witnesses of the developing political conflict. Only in the first years of the eighteenth century did the press policy begin to develop, mainly thanks to Robert Harley, $1^{\text {st }}$ Earl of Oxford and Earl Mortimer, Lord Treasurer of Great Britain whose "press policy [...] demonstrated the way in which the dual weapons of propaganda and proscription could be exploited by the government" (Downie 1979: 3). Harley's achievements in organising the effective press policy overwhelmed the Whigs and "only by 1714, under the inspired leadership of Richard Steele, did the opposition come up with an answer to the ministerial challenge" (Downie 1979: 3). This rivalry between Whig and Tory defined the political situation in early eighteenth-century Britain and laid the foundation for the development of the ministerial machine of propaganda aimed at discrediting opponents and justifying the policies of the government. The rhetoric adopted by the contemporary political writers included the reason-passion bias so inextricably associated with the philosophical background of the 'Age of Reason'.

The seventeenth-century philosophical inheritance regarded passions as "an overbearing and inescapable element of human nature, liable to disrupt any civilised order [...] unless they were tamed" (James 1997: 1). This depiction fully corresponded with the opinion of one of the most influential philosophers of the time, Nicolas Malebranche. Malebranche essentially agreed with Cartesian dualism defining the mutual relation between body and soul in terms of the passions and the way in which emotions impact on the individuals:

the mind and the body are two kinds of being so contrary to one another that those who believe that the soul's emotions necessarily follow the movement of the spirits and blood believe something without the faintest plausibility $[\ldots]$ At present time [...] the body acts too forcefully on the mind. Instead of humbly representing its needs to the mind, the body tyrannises it and tears it away from God (Malebranche 1997: 339).

This purely negative perception of the emotions was a dominant trend in eighteenth-century philosophical thinking and was shortly and relevantly summarised by Alexondra Hultquist, by including the idea that

the passions were thought to be public, rather than private; they were a social phenomenon which was anchored by a shared morality. Emotions were not settled to a particular person, but seemed to wander from individual to individual, belonging to no one. Because of this almost physical movement, they were remarkably hard to pin down, and caused a great deal of anxiety [...] passionate experience should cultivate judgement and moderation; the expression and understanding of the passions should be controlled and used for the public good (2016: 88).

The control over passions was the subject of works targeted generally at men connected with political power and before offering advice on how to rule successfully they wanted to help men become virtuous by revealing "how passions are raised in them, how they rebel against reason, how they seduce understanding 
and what sleight they use to enslave the will" (Senault 1671). ${ }^{1}$ Thus, the number of seventeenth-century treatises and works of advice for so-called princes strongly conveyed the relationship between knowledge of passions and its uses in controlling others. On the one hand the prince was taught how to control his own passions, and on the other how to manipulate the passions of those who surrounded him. This somewhat Machiavellian understanding of the nature and uses of the passions continued and further developed during the course of the eighteenth century which, according to Aleksondra Hultquist, "perhaps more than any other era [...] was embroiled in trying to best understand how the passions created public systems, such as governmental structures, and how controlling those passions would lead to a harmonised society" (2016: 88). Obviously, it is not a coincidence that the contemporary attitude and understanding of the passions and their place in human life was reflected in the name given to the period as a whole: the Age of Reason. The negative connotation of passions complemented with positive associations of reason and formed a rhetoric used by both sides of the political conflict in early eighteenth- century England. This rhetoric aimed at producing a self-portrait which reflected social responsibility and rationality while simultaneously showing one's rival to be both irresponsible and irrational; this tactic was summarised by Brian Cowan when he stated that "critical appeal to reason was used and invoked by contemporaries as legitimisation strategy for their arguments" (2016: 62). Somewhat paradoxically, it was during the Age of Reason, when the attitude towards passions changed. The influence of Descartes' dualistic view of human nature and his positive approach paved the way to a revision of the traditional understanding of the passions by treating them as one of the major human faculties rather than as part of the will (Dixon 2003: 76-79, James 1997: 85-108). Furthermore, John Locke insisted that the human mind could be trained to control passions (Locke 1824: 254). In English philosophy, Anthony Ashley-Cooper, $3^{\text {rd }}$ Earl of Shaftesbury also played a major role in spreading a far more positive view of passions, dividing them into those he considered 'natural' and 'unnatural' and through this process identifying the various passions with the sources of human goodness:

Since it is therefore by Affection merely that a Creature is esteem'd good or ill, natural or unnatural; our business will be, to examine which are the good and natural, and which the ill and unnatural Affections (Shaftesbury 1999: 170).

From this perspective, the article sets out to trace the evolving rhetoric of passion and reason deployed in the early eighteenth-century English Whig newspapers with their emphasis on the unifying tendencies of the Whigs associated with a reasonableness of argument and outlook as opposed to the Tory politics of division, an approach linked with destruction and irrationality. It is within this context that the new approach towards passions in Steele's periodicals will be presented.

'The passions' was a well-known topic discussed repeatedly in eighteenthcentury essay periodicals and the means by which this issue was analysed by 
particular authors forms a subject of much scholarly interest. For example, Endre Szécsényi while elaborating on early eighteenth-century philosophical notions of wit and laughter in Addison's writings, investigates the process of shifting the traditionally negative connotation of passions and concludes that it was possible to "get rid of the constraining and determining passions [...] in turning them into polite affections or aesthetic sentiments" (2007: 90). McKenzie analysed the treatment of passions in Johnson's Rambler (1986). Earlier Peake (1960) and Macaree (1976) had traced the notion of passions in the writings of the eighteenth-century authors; however, not necessarily with reference to their journalistic output. Of crucial importance for this article is the study on Locke's theory of emotion in The Spectator (Sodano 2017) where the author points at fundamental differences between Addison's and Steele's interpretation of passions: "Both Addison and Steele agree that emotions are controllable feelings; they differ, however, on the question of whether or not one ought always to control them" (Sodano 449). Passions as a particular form of Tory rhetoric against 'The Whig', represented in the flagship Tory press organ The Examiner ${ }^{2}$, developed on the bases of a passionsreason bias and was recently the subject of analysis (Kozak 2017).

The Examiner constituted a 'right-wing' organ and a cutting edge of anti-Whig propaganda. The editors of the periodical included Henry St John, William King, Jonathan Swift, Mary Delarivier Manley, William Oldisworth and Joseph Browne. Little is known about the origins of the paper and scholars have put forward theories concerning its original function either as an organ "specifically designed both to justify past actions and indicate future ministerial policy" (Lock 1983: 28) or as a paper representing not Oxford's projected moderate administration but St. John's supporters (Patterson 1974: 154). The character of The Examiner, as a ministerial essay periodical, determined its content, which was mostly aimed at discussing and supporting the current government's aims and policies. The Examiner's conformity to the general opinion that the so-called passions are the source for "blindness [...] cast over the Understanding" (I, no. 20) is further developed and elaborated in an essay which discusses "the mutual Entercourse between the Conscience and the Passions" and "the Mischiefs that may follow from such a Dependence" (III, no. 19). The Examiner's opinion on passions is clearly negative. The image emerging from the Examiner's four-year-long discourse ${ }^{3}$ was multi-layered, consisting of a persistent representation of the irrational Whig, riven by passions which ultimately drive him to destabilise the country in an attempt to regain political power. Moreover, in the Examiner's opinion, the destructive force of passions was debasing not only the members of the Whig party but also its supporters. In effect, the Whigs' authority was being eroded by their tendency to appeal to the passions above all else; the devastating consequence of which was the transference of their emotive and tyrannising methods onto their erstwhile followers. The newspaper finally 'revealed' the whiggish use of 'pathetic writing' as the manipulative tool wickedly employed to appeal to the readers' emotions rather than to the higher faculty of reason (Kozak 2017: 80-86).

In contrast, the strategy exhausting the rhetoric of passions and reason employed by flagship Whig writers varied considerably in its methods for criticising and undermining political opponents. The corpus chosen for the analysis of 
this strategy includes The Spectator, The Englishman and The Reader. These journals, all edited by Richard Steele (The Spectator together with Joseph Addison), do not exhaust the subject, but they form a canon sufficient enough to delineate the evolution of Steele's anti-Tory rhetoric. The relatively short period of publishing of these three periodicals (1711-1714) and the change of the tools of rhetoric used for criticising political adversaries (as it will be shown in the article), may point at the increasing necessity to win over the audience in the face of everlasting popularity of the government newspaper - The Examiner. The analysis of Steele's writing enables us to identify certain features of his rhetoric and the change is more noticeable. However, the similar research in terms of other flagship Whig writers (e.g. Daniel Defoe) might be of great advantage to define a broader perspective of identifying the core features of anti-Tory, or more precisely anti-Examiner propaganda. The Examiner, remaining the main Tory press organ between 1710-1714 (and in the face of ever-changing Whig titles), may justify the equivalency stated between anti-Tory and anti-Examiner propaganda.

The substantial difference between first-rank Whig and Tory essay periodicals is repeatedly characterised by their content relating to politics. In the light of this, newspapers like The Examiner, The Englishman and The Reader are defined as being strongly political and, as a direct consequence, stigmatised as less interesting (Marr 1970: 47, 49; Powell 2012: 12). In fact, such an opinion among researchers and perhaps also eighteenth-century readers could be the result of the strategy employed by Addison and Steele who while designing their most famous works, The Tatler and The Spectator, decided to make political issues less obtrusive. Indeed, explicit criticism staged in The Examiner might have appeared to the readers as having been written by a passionate author and this aspect was repeatedly emphasised by Addison and Steele. From this we can see that in their shared editorship of The Spectator, the mild political satire was aimed at contrasting and highlighting the Examiner's political narration.

\section{Steele's tactics of manipulating the audience}

Displaying an image of a passionate rival logically entailed creating the self-portrait of a calm, considerate and reasonable person with impartiality of judgement. Of course, this was a rhetorical device used by both sides of the partisan conflict. Steele and Addison, however, in addition to direct critical remarks against 'Tory reasonableness', used the party stereotype of the 'smaller' country gentry with their Jacobite leanings together with the persona of the reasonable Tory who has more than just a hint of impartiality about him (as presented in The Examiner) and subtly ridiculed this compacted image in The Spectator. Indeed, rather than implementing a savage satire, they invented Sir Roger de Coverley. Clive Lewis very accurately pointed out that through the figure of Sir Roger "the enemy far from being vilified, is being turned into a dear old man. The thought that he could ever be dangerous has been erased from our minds; but so also the thought that anything he said could ever be taken seriously" (1945: 2). The most useful aspect the Whiggish writers were able to create in respect to this persona was the 
overall calmness of Sir Roger, a calmness which was continually put to extremes. The portrait that emerged from this was of an older country gentleman, separated from London life and so uninvolved in it or overwhelmed by his own prejudice of it that he would even not sleep at an inn kept by a Whig supporter (The Spectator no. 126). Addison and Steele's technique seemed to exemplify perfectly Dryden's advice that a perfect satire should have a "fineness of a stroke that separates the Head from the Body, and leaves it standing in its place" (Dryden 1808: 94). The subtlety of Addison's satirical image of a Tory embedded in the figure of Sir Roger was strengthened by its juxtaposition with Sir Andrew Freeport, a successful merchant who eventually represents not only a self-made man but whose prosperity contributed to England's richness. Despite Addison's favourite approach towards his characters being satire (visible as well for example in his approach towards another character from The Spectator - Sir John Anvil), the treatment of Sir Andrew Freeport seems rather not surprisingly serious. The positive and highly appreciative statement towards merchants was explicitly formulated in number 69 beginning with "there are not more useful Members in a Commonwealth than Merchants". What is more, Sir Andrew is depicted in his old age, as a successful man who decided to invest in landed estates, improving the countryside in the process. From this perspective the Tory landowner is transformed into an ineffective manager, who inadvertently prevents the economic development of England.

The clarity of Tory criticism of 'The Whig' so visible in its closeness to rage and exasperation displayed on the one hand through grotesque figures such as yahoos, toads or bugs and direct association of the enemy with the destructive force of passions on the other, contrasts with the subtle treatment displayed in the case of Sir Roger. Lewis compared both and summarised that Tory satire "is like a thunderclap" while the Whig method "is more like the slow operation of ordinary nature, loosening stones, blunting outlines, modifying a whole landscape with 'silent overgrowings' so that the change can never be quite reversed again" (1945: 3). While the Examiner openly discusses politics, the Spectator seems to pretend not to be particularly engaged in politics, and debates less serious matters so as not to discourage readers by tiring and annoying them with the existing political conflict. However, the outcomes of this milder form of satire were apparently beyond their authors' expectations. Although the creation of the figure of Sir Roger de Coverley is attributed to Addison, it seems unlikely that in the journal established by both Addison and Steele, the ideas for essays were not agreed before their publication. Nevertheless, the change in approaching the enemy noticeable in Steele's journals that followed The Spectator (as analysed later in the article) may point to his disappointment at the form of satire employed by Addison. Therefore, it seems rather unsurprising, that after a relatively short period of time The Tatler and its successor, The Spectator (both exclusively edited by Steele), were substituted with newspapers that were significantly more political in character: The Guardian, The Englishman and The Reader. The straightforward critique of the Whigs that was permanently being run in The Examiner seemed to have a stronger impact on readers and therefore was imitated in Steele's political papers that followed The Tatler and The Spectator. 
The charge of being overwhelmed with passions became the basis for mutual discrediting in the eyes of readers. However, adopting The Examiner's direct and unambiguous narration, which was so openly hostile towards its political opponents and therefore easily accused of being passionate, would discredit Steele as an authoritative writer because he would be using the very same method he had criticised. In order to employ explicitly fierce and emotionally charged language and still create a false impression of being relatively distanced and not deeply affected by the partisan political war which was taking place, Steele shifted emotional reaction against The Examiner from himself to the audience. With this in mind, he partly changed The Englishman into a forum for readers angered and frustrated with The Examiner's essays. The practice of including "readers' voices" seemed even demanded in the newspaper market since the sheer number of newspapers expressing authorial opinions on their political rivals might ironically have given the impression that society as a whole was excluded from the narrative battle led between the various authors. Such a perception could easily have influenced the newspapers' reception among the target audience tired with the constant mutual accusations and in consequence diminish potential authority of the periodicals among their readers. Adopting the practice of publishing readers' correspondence not only gave the impression of engaging the society in political life but first and foremost enabled Steele both to distance himself from the audience and at the very same time be part of it.

Distinguishing himself from the editor of The Englishman, Steele in one of the letters published in the paper and signed with his real name, uses emotionally charged language aimed at presenting the Examiner's rage, violence and ruthlessness: "The Examiner is no more a Tory, than a Huzzar or a Bandito is a Soldier. There are certain Rules, which no Anger, no Adherence to different Interests, no Dissention in Opinion, should make honest Men break through; but this Wretch observes no Law, but being most outragious against those who ought to be most sacred from Violation" (no. 13). Through the words of Ralph English, one of the Englishman's correspondents, the Examiner was explicitly associated with foolishness, madness or even insanity: "If he [the Examiner] is to enjoy the Liberties and Freedoms of a Court Fool, and speak of all Persons and Things without Exception, according to his Folly, it is absolutely necessary to keep Pen and Ink out of his Way; for they are most dangerous Instruments, and in the half-Wit will do more Mischief than Sword and Dagger in the Hands of a Madman" (The Englishman no. 43). The people's fury was repeatedly expressed in the number of abusive terms directed at the Examiner which included such names as "Wretch" (no. 4), "Scoundrel" (no. 15), "Rascal" (no. 4, 13), "Destroyer of all things" (no. 57), "silly Rogue" (no. 4), "diabolical Worm" (no. 13), "the Brute" (no. 13), "Ruffian" (no. 13) or "awkward Wittol" (no. 43). This image was even strengthened with threats of vengeance and physical violence. John Smith, another correspondent to the Englishman, menaced: "I will beat him for that in a very little Time [...] I shall shew him that I can cut the Head as well as the Feet" (no. 4). Apparently, the only thing saving the Examiner from such a miserable state was the fact that much to the chagrin of the alleged correspondents, he remained anonymous. Displaying the extremes of passions that people could be driven to was an 
element of propaganda used both by Tories and Whigs alike. While the Examiner accused Whig papers of 'pathetic writing' which unnecessarily stirred people's passions, Steele indirectly showed that the Examiner's discourse stirred people's passions even without any appeal to pathos.

The practice of submitting letters to himself enabled the editor to be part of the audience frustrated and annoyed with the Examiner and therefore on the same level with the other correspondents. As a consequence, he managed to create his image - as the editor of The Englishman - of a reasonable and objective mediator who despite his obvious criticism of the passionate Tory uses calm and considerate narration in contrast to the readers' published letters. Employing this technique of separating the voices of individual people from the editor's narration, Steele displayed himself as the level-headed collector of the readers' and contributors' passionate form of narration filled with grief and resentment. What is more, such a means of manifesting the reader's discontent with the Examiner's writings seemed to have greater impact than the editor's own criticism. Although there is no evidence that the letters are indeed genuine, the fact that Steele repeatedly published his own signed contributions ${ }^{4}$ may indicate that at least some of the correspondence from other readers were the Englishman's own production as well. Steele's letters submitted to The Englishman must have seemed rather awkward when he, according to his literary practice (Hyland 1991: 19), revealed his identity in the last number of the paper.

Within a war of words associated with the ferocious debate led between the newspapers, the negative opinions concerning The Examiner and Tory politics included in the readers' correspondence, particularly in the case of limited voting rights, played more or less the role of contemporary polls, which aimed to show the general support for the Whigs and perhaps influence other members of society in their favour. In fact, shifting the fierce debate from author to reader proved an excellent means of creating an anti-Tory atmosphere without being identified as its direct source.

An interesting aspect of rhetoric used in The Englishman is juxtaposing the Examiner's passionate and fierce discourse with that of the humbleness of one of The Englishman's correspondents - Richard Steele - offended by it. In one of his numerous letters written to himself, Steele admitted:

I have really taken a secret Pleasure in seeing him [the Examiner] employed in villifying me, and enjoyed the Merit of diverting him that while throwing his Slander upon Persons whom it is a public Injury to calumniate [...] I consign to him the full Liberty of saying what he pleases, provided he will not fall upon Men whom I am obliged, as a good Subject and an honest Man (no. 13)

The role Steele assumed was clearly the role of a victim.

Furthermore, in this form of narrative, the first wave of grief and resentment steadily fades away to be replaced by an attitude of humility which in turn evokes the image of a Christ or Christ-like figure who humbly accepts the abuse that has been dished out. Such a narration seeks to strengthen the image of the passion- 
ate, malicious and vindictive Examiner as an individual who expresses his hostility towards the ordinary man who humbly agrees to his miserable fate in order to divert the Examiner's attacks from those who are truly noble. In this way the correspondent was presented as the victim of the Examiner's allegedly abusive narration that, like Christ, suffers for others. Undoubtedly, the image of a victim aimed to arouse compassion among Steele's audience and at the same time feed hatred towards the Examiner. Furthermore, the humbleness of the correspondent offended by (in their opinion) the Examiner's malicious narration forms part of a wider rhetoric of passions. The calmness and reasonableness of the former associated not only with the detection of the narrator's malign intentions but also the passive attitude towards these intensions, logically places the Examiner on the opposite side - namely as being passionate and therefore irrational.

Perhaps due to the charge of forging letters (The Examiner IV, no. 38, 16 Oct. 1713) and the limited effectiveness of the adopted tactics, Richard Steele abandoned the idea of a 'forum' in favour of explicit accusations expressed directly by himself. Therefore in The Reader (1714), a newspaper established a few months after closing The Englishman and also aimed to counter-attack The Examiner, he widely used the rhetoric of passions and accused the Examiner of disabling the political debate which could not be properly led when passions take control over reason. The Examiner was described as one who "a great while had nothing else to utter but meer Words of Passion" (no. 2). As one of the proofs he provided an extract from The Examiner, which through a number of exclamation marks aimed to exemplify its lack of self-control and its destructive inflammatory effect on the readers:

he says of them [Whigs], That instead of making Atonement for their past Sins, they are still reviving their own Shame and Infamy, and ringing over the same Chime in our Ears without ceasing, Popery!, the Pretenter!, French Tyrrany! Dunkirk not demolished! Toby Butler! The Highlands! Swarms of Jacobites! The Catalans! The Peace! Importation of Jesuits! Invasions from Bar-le-Duc! All these stale noisy Topicks, are still flying about our Ears like Wild-fire wrapp'd up in Paper (The Reader no. 2).

\section{The image of the Examiner}

Steele's newspapers with their obvious Whig support constituted a pillar of antiTory propaganda and were directed mostly towards The Examiner as the main Tory press organ. The abovementioned excerpt depicting the Examiner as overwhelmed by passions formed continuation of the rhetoric aimed at revealing his irrationality. This image was further complemented with the elements that contributed to the wholly negative portrait of the Examiner and which were mostly based on separating the newspaper and its editors from the Tory party. Steele's attempts not only to quarrel but to show the Examiner's disinterest in following any of the parties was employed as an attempt to exclude the Examiner from political life: "I know no pretentions the Examiner has to lift himself with either 
party. He is out of the Line of Battel, doing all the Mischief he can between both Camps" (The Englishman no. 13). Steele's constantly repeated association of the Examiner with a criminal eventually formed a subtle message to both parties that "it is the Interest of either of the Two [parties] to hang him up wherever they take him" (no. 13).

Similarly to the tactics applied by the Examiner which was grounded on the notion that no one driven by passions should be a proper person to participate in political life (Kozak 2017), Steele made further effort to eliminate the Examiner from the political scene by depicting him as hostile not only to both parties but first and foremost an enemy to the Queen. In doing this, once again the Examiner's narration is linked to the overwhelming impact of passions and conveyed through the words of one of The Englishman's correspondents, Ralph English: "The ungoverned Rage of the Examiner and other Writers, against those whom they distinguish by the Word Whigs, has made them run into the most disrespectful Insinuations against the Queen's Majesty" (no. 43). The Examiner's anti-monarch attitude was further emphasized by exposing him as enemy of the Queen and in consequence as that who only pretends to be a loyal subject and, in truth, is the real source of divisions within the nation ${ }^{4}$. In no. 57 of The Englishman, Steele using the metaphor of family, describes the Queen as "the Mother of all her People" uniting all her children (society). This unification included the removal of Party divisions and substituting them with the rule that "all Men according as the Law makes them qualified, and their Virtues and Parts make them fit". The Englishman's suggestions of removing the party divisions from the political life of England, enables him to strengthen anti-Examiner propaganda and to point out that the Examiner's aims are opposite ones to the Queen's policy of unification: "Examiner's Violence and Partiality hath done more to sharpen them [Parties], than to take off their Edg [sic]" (no. 57). On the one hand, the Examiner is depicted as the destroyer of peace, and on the other Steele tries to end the Examiner's critical remarks about the Whigs by referring to him as a criminal and stating that any "who shall dare to insult and exasperate the other as Enemies, they are Sycophants instead of Friends, and rob her [the Queen] of her best Treasures, which is the Love of all her People" (no. 57). Steele would appear then as a fighter for the unification of society and depicted the Examiner as the very opposite. In this way, according to Steele, the Examiner was not the rival of the Whigs but the enemy of the people and for whom it is "painful [...] to think of any Englishman's Happiness" (no. 13).

What is worth noting is Steele's clearly visible effort not to address Tories directly. In doing this he very skilfully avoided blaming them and instead he was revealing the mischievous policy of the Examiner "and his Friends", "these Heads" or "these Men" (The Englishman no. 57). Thus, the edge of criticism was narrowed so as not to offend Tory supporters. Instead he reinforced the idea of redirecting any blame from Tories and transferring it to the Examiner.

Steele further continued the tactics of increasing internal divisions within Tory circles addressing their natural supporters. In his attempts to evoke disagreement between Tories and Churchmen he depicted the former as noisy men and compared them to "Weather-cocks and Clappers of the Steeple" as contrary to 
"the sober, and laborious, and peaceable Churchmen" (The Englishman no. 57). He goes on to refer to the Aristotelian concept of form and matter and analyses the relation between the Church and the State. Again, in a metaphorical language reflecting the coexistence of Soul and Body, he depicts the Church as the equivalent of the latter and as naturally subjected to the State which is compared to the Soul. From this perspective his conclusion that "the more rebellious and stubborn Body is to the gentle Government of the Soul, the more it procures to it self both outward and inward Mischiefs of Diseases and evil Accidents" (no. 57) sounds like a sinister warning. In the case of the Churchmen Steele repeats his technique of shifting the blame and eventually identifies the Church's errors with the malicious Examiner's propaganda because "since the Examiner and Oracles of Policy have opened themselves, many Clergymen are for giving unreasonable Preferences of the Church to the State, and advance such Notions for the securing the former, as if put in practice will infallibly destroy the whole" (no. 57). The Examiner is accused of destroying the whole naturally formed "political constitution" through deceiving its Body (the Church), which will negatively affect the performance of the Soul (the State). Revealing the Examiner's allegedly mischievous plans towards the Churchmen is logically interconnected with the use of one of the more powerful modes of persuasion, namely the appeal to reason. Steele stated that the Examiner's

Folly and Contradiction is covered by the general Profession of Zeal for the Church: and many Churchmen, I include many even of the Clergy, have been carried away with the Cry. But let our Senses be never so much deafned [sic!] with the Cry of the Church, or dazzled with the gilded Pretences of some Politicians, nothing can prove the Clergy more to be Men of Conscience, or truly Loyal, than a strict, nay, scrupulous Adherence to the most solemn Oaths they have so often taken, both of Allegiance to the present Establishment, and Abjuration of the Pretender (The Englishman no. 57).

Such narration aimed at opening the Clergy's eyes by forcing them to notice the secret mischievous plans of the Examiner and eventually enabling them to distance themselves from it. The clearly noticeable element of the propaganda included in the cited extract is the transference of blame from the Churchmen to the Examiner and showing it once again as the source of the divisions and conflicts in society as a whole. The mischievous Examiner's policy creates the situation of a stupefied Church remaining in a kind of lethargy which might have far reaching consequences because "the more untractable to, and negliegent of its [the Church's] excellent and sublime Precepts the People are, the more they degenerate into Atheism, Profaneness, Debauchery, and all manner of Vice, and hasten with speed into their own Ruin" (The Englishman no. 57). In this way the Examiner, through his malicious strategy towards the Churchmen, becomes the source of the internal degeneration of society.

Eventually, Steele attempts to disrupt the traditional association of the Tories with the High Church as opposed to the Whigs with the dissent. He also stresses 
the connection between the Tories and Jacobites and identifies the former as traitors. The emerging picture of Tories would constitute then fierce partisan politicians and their similarly fierce followers who are the source of divisions within the Church and in the wider society, spreading chaos throughout the country. What is more, such opinion is expressed by the Whig editor who depicts both himself and the Whigs at large as loyal subjects without partisan affiliation, craving to unify the nation.

\section{Conclusions}

The rhetoric of passions played a significant role in discrediting rivals in the early eighteenth-century English press. In Tory periodicals, Whigs represented the uncontrolled passionate element in the body of the state while the 'practical' Tory government was presented as the guarantor of control over the whiggish passions through the very act and process of reason, which would eventually lead to a harmonised society. Such Tory self-portraits were ridiculed in The Spectator which in the figure of Sir Roger depicted a far too conservative, old-fashioned and non-progressive Tory, unaware of social change and definitely not someone prepared for running the government.

The Examiner claimed that the Whigs were deceiving the nation with their use of 'pathetic writing'; Whigs, on the contrary, accused the Examiner of disloyalty towards the Queen and dividing the nation. Showing the Examiner as the enemy of the Queen was supposed to be the basis for evoking people's aversion or even contempt towards the paper. The logical continuation of such rhetoric was depicting oneself as the opponent to the harmful activity of the rival. Therefore, The Examiner emphasised its own rationality, objectivity and impartiality and juxtaposed all this with the emotional fervour of Whigs, while the Whigs presented their own uniting tendencies aimed at removing partisan controversies that divided society in contrast to the Examiner's readiness to sharpen the conflict. Steele persistently presented Whigs and their supporters not as the opponents in a partisan conflict but as the sober members of political life encouraging the resignation from partisan debate and, instead, relying on the Queen who would "let all see, that her Crown is not to be sunk down to be a Partizan of either Side [...] but that she is over both" (The Englishman no. 57). The only obstacle that prevented reaching this plan was the Examiner's fuelling of hatred. In result, the real victims of the Examiner's attacks were not only Whigs but the whole nation, including the Queen. Steele's vision comprised the image of a nation that forms a natural constitution of the government (the Soul) and the Church (Body) united under the rule of the Queen, and not riddled with party divisions; the Examiner, meanwhile, was depicted as the destroyer of this natural order.

The image of the Examiner that emerges from Steele's propaganda is of a criminal, blamed for all the mischievous actions reflected in establishing and sharpening multi-layered divisions among the society, which all eventually leads to chaos and disorder. Therefore, in the case of the portrayal of the Tory as displayed by Whigs the emphasis was laid not on the aspect of 'inflaming' the nation through 
pathetic writing but on dividing it. Furthermore, the clearly recognisable strategy used in Whig newspapers consisted of shifting the frustration from the editor of the newspaper onto its readers. As a result, the newspapers contained the relatively balanced comments of the editor with the readers' resentful letters inserted as part of the discourse. The emerging image gave a powerful impression of the rising anger of the 'middle class' representatives offended by Tory papers, mainly The Examiner. Within the rhetoric of passions and reason, the correspondents' attitude of humility that eventually wins over their fury can be interpreted as the victory of reason over emotions.

The evolution in Steele's journalistic productions allows the contemporary reader to delineate key changes in his strategies for achieving political goals and, at the same time, discredit the Examiner. Beginning with the mild satire contrived in The Spectator, he shaped a tool - The Englishman - enabling more explicit criticism and used real or forged correspondents to exemplify people's complaints about Tory politics. Steele used emotionally charged language and though being the editor of the newspaper, he still managed to avoid being directly identified with it. Eventually, however, he resigned from keeping up such appearances and in The Reader he decided to run the whole anti-Examiner propaganda himself. As a result, a dissonance between Steele's alleged non-adversary and supra-party literary strategies and real manipulative exclusionary practices is clearly visible. What is more, the explicit demonstration of readers' fury in The Englishman as well as the editor's anger in The Reader (in contrast to The Spectator), are in line with Steele's interpretation of the passions as an element that should not be entirely controlled.

In the broadest sense, the rhetoric of passions formed an essential part of the discourse represented by both sides of the political conflict, highlighting the need for reason to rule over the emotive and emotional; an argument entirely consistent with the wider, philosophically grounded debate concerning 'the passions' and their place in the cultural, social and political world. However, it is essential to understand the markedly different ways in which both sides of the political scene reached their conclusions and methods for depicting the rival as the destroyer of order in the spirit and body of the state.

\section{Notes}

The citation is part of the prefatory letter where no pagination is given.

Further references to the newspapers will be made either to the magazines (titles written in italics) or to their personas (titles written in upright font).

The Examiner was printed between 3 August 1710 till 26 July 1714 and later continued between 10 September 1715 and 7 March 1716. The four-year-long discourse mentioned in the article refers to the first four years of its publication, ended by Queen's Anne death.

$4 \quad$ Steele used this practice also in The Guardian (no. 54, no. 63).

$5 \quad$ Number 57 of The Englishman (15 February 1714) forms an answer to an issue of The Examiner published several weeks before $\left(30^{\text {th }}\right.$ October 1713$)$, where the Examiner accused Steele of "Libelling the Queen and the Ministry" (IV, 43). 


\section{References}

Cowan, Brian (2016) Making publics and making novels. A post-Habermasian perspectives. In: Downie, Alan J. (ed.) The Oxford Handbook of the Eighteenth-Century Novel. Oxford: Oxford University Press, 55-70.

Downie, Alan J. (1979) Robert Harley and the Press. Propaganda and Public Opinion in the Age of Swift and Defoe. Cambridge: Cambridge University Press.

Dryden, John (1808) Essay on Satire. In: Scott, Walter (ed.) The Works of John Dryden, vol. XIII. London: William Miller.

Dixon, Thomas (2003) From Passions to Emotions. The Creation of a Secular Psychological Category. Cambridge: Cambridge University Press.

The Englishman, https://books.google.pl/books?id=IY2UnI4L6g8C\&printsec=frontcover $\& \mathrm{hl}=\mathrm{pl} \#_{\mathrm{v}}=$ onepage\&q\&f=false [Accessed on: 15/06/2018].

The Examiner, https://books.google.pl/books?id=KigTAAAAQAAJ\&printsec=frontcover $\# \mathrm{v}=$ onepage\&q\&f=false [Accessed on: 15/06/2018].

Hultquist, Aleksondra (2016) Eliza Haywood's progress through the passions. In: Kerr, Heather; Lemmings, David and Robert Phiddian (eds.) Passions, Sympathy and Print Culture: Public Opinion and Emotional Authenticity in Eighteenth-Century Britain. Basingstoke: Hampshire Palgrave Macmillan, 86-104.

Hyland, Paul (1991) Naming names: Steele and Swift. In: Hyland, Paul and Neil Sammells (eds.) Irish writing. Exile and Subversion. New York: Palgrave Macmillan, 13-31.

James, Susan (1997) Passion and Action: The Emotions in Seventeenth-Century Philosophy. New York: Oxford University Press.

Kozak, Katarzyna (2017) The hurry and uproar of their passions: images of the early $18^{\text {th }}$ century Whig. English Literature 4, 73-89.

Lewis, Clive S. (1945) Addison. In: Essays on the Eighteenth Century Presented to David Nichol Smith in Honour of his Seventieth Birthday. Oxford: Clarendon Press, 1-14.

Lock, Peter F. (1983) Swift's Tory Politics. London: Duckworth.

Locke, John (1824) An Essay Concerning Human Understanding. Vol. I. London: Printed for C. and J. Rivington.

Macaree, David (1976) Reason and passion harmonized: The Drapier's Letters and the language of political protest. The Canadian Journal of Irish Studies 2 (2), 47-60.

Malebranche, Nicolas (1997) The Search After Truth. In: Lennon, Thomas M. and Paul J. Olscamp (eds.) Cambridge Texts in the History of Philosophy. Cambridge: Cambridge University Press.

Marr, Simpson G. (1970) The Periodical Essayists of the Eighteenth Century. New York: Phaeton Press.

McKenzie, T. Alan (1987) The systematic scrutiny of passion in Johnson's Rambler. Eighteenth-Century Studies 20 (2),129-152.

Patterson, Paul B. (1974) Robert Harley and the Organisation of Political Propaganda [Ph.D. Diss.]. Charlottesville: University of Virginia.

Peake, Charles (1960) Swift and the passions. The Modern Language Review 55 (2), 169-180.

Powell, Manushag N. (2012) Performing Authorship in Eighteenth-Century English Periodicals. Lewisburg: Bucknell University Press.

The Reader, https://books.google.pl/books?id=jwk3YssWsz4C\&printsec=frontcover\&$\mathrm{dq}=$ lover+reader+steele\&hl=pl\&sa=X\&ved=0ahUKEwiNs7_-5p7cAhXJDcAKHTTqDkk Q6AEIKDAA\#v=onepage\&q=lover\%20reader\%20steele\&f=false [Accessed on: 15/06/ 2018].

Shaftesbury, third Earl of (1999) Characteristics of Men, Manners, Opinions, Times. Edited by Lawrence E. Klein. Cambridge: Cambridge University Press.

Senault, Jean-François (1671) The Use of Passions, (transl.) Henry Earl of Monmouth. London: John Sims. 
Sodano, Joel P., Uneasy passions: The Spectator's divergent interpretations of Locke's theory of emotion. The Eighteenth Century, 58, 4, 449-467.

The Spectator, https://books.google.pl/books?id=gCZMAAAAYAAJ\&printsec=frontcove $\mathrm{r} \& d q=$ spectator+addicon\&hl=pl\&sa=X\&ved $=0$ ahUKEwiBldKe $4 p 7$ cAhVKbVAKHbJ6BD MQ6AEIKjAA\#v=onepage\&q=126\&f=false [Accessed on: 15/06/2018].

Szécsényi, Endre (2007) Freedom and sentiments: wit and humour in the Augustan Age. Hungarian Journal of English and American Studies (HJEAS) 13 (1/2), 79-92.

KATARZYNA KOZAK works in the Institute of Linguistics and Literature Studies at Siedlce University of Natural Sciences and Humanities, Poland. She earned M.A. in English Philology from the University of Warsaw and Ph.D. in history from Cardinal Stefan Wyszyński University in Warsaw. Her main areas of interest are connected with the interdisciplinary research lying between literature and politics concerning the process of shaping literary circles and their role in ideological formation of the society in early modern period. This comprises the research on the $18^{\text {th }}$ century English fiction and non-fiction, mainly essay periodicals, and the language of propaganda. Other research interests include the relationship between the journalism and the emergence of the English novel and the theory of the novel at large. She is the author of a number of articles concerning her field of interest and lectured among others at University of Balearic Islands, Limburg Catholic University College and Lucian Blaga University of Sibiu.

Address: Katarzyna Kozak, Ph.D, Institute of Linguistics and Literature Studies Siedlce, University of Natural Sciences and Humanities, ul. Żytnia 39, 08-110 Siedlce, Poland. [katarzyna.kozak@uph.edu.pl] a contractual license or exception or limitation to relevant rights. 
